\title{
Testemunho: um acontecimento na estrutura ${ }^{1}$
}

Bethania Sampaio Corrêa Mariani*

\section{Resumo}

Este artigo trata da questão do testemunho do ponto de vista da análise do discurso e da psicanálise. A noção de real é mobilizada, circunscrevendo um impossível de ser simbolizado tanto na história como na linguagem. Discute-se É isto um homem?, de Primo Levi, e o documentário $A$ morte inventada, dirigido por Alan Minas.

Palavras-chave: Testemunho. Real. Análise do discurso. Psicanálise.
Le réel, c'est ce reste de toute histoire qui échoit au sujet, excédent le sujet lui-même. Le réel est sa part la plus intime et en même temps la plus étrangère, la condition même de

la subjectivation. (THÉRON, 2004, p. 9)

El trauma no se cura por la memoria, y aun menos por el olvido. Por eso una de las formas de tratar lo real del trauma es bajo la forma de la historización.

Pero la historización no tiene una significación única. [...] La Shoa, el genocidio más devastador del siglo pasado no cesa de escribirse. (BLEGER, 2010, p. 37)

\footnotetext{
Doutora em Linguística pela Universidade Estadual de Campinas. Professora titular do Departamento de Ciências da Linguagem, Instituto de Letras, Universidade Federal Fluminense. Bolsista CNPq e do Cientista do Nosso Estado Faperj. Pesquisadora do Laboratório Arquivos do Sujeito. Docente do Programa de Pós-Graduação em Estudos de Linguagem da Universidade Federal Fluminense. E-mail: bmariani@id.uff.br
} 
Antes de introduzir o ponto central deste texto - a insistência do testemunho e a (im)potência para os dizeres - retomo o título, tendo em vista a alusão feita a dois livros: o de Pêcheux, Discurso: estrutura ou acontecimento (2006); e o de Leite, $O$ acontecimento na estrutura; o real da língua na teorização sobre o discurso: a hipótese do inconsciente (1994).

\section{Palavras iniciais}

Orlandi (2006, p. 5), retomando Pêcheux, sinaliza que a análise do discurso está situada em uma posição de entremeio no campo das disciplinas humanas e sociais, uma vez que trabalha com a materialidade singular do discursivo, a qual não é sem o processo de constituição mútua entre o linguístico e o histórico. Essa materialidade é discutida por Pêcheux como um espaço discursivo não logicamente estabilizado, pois na materialidade discursiva há pontos de real, em que estrutura e acontecimento funcionam por desestabilização. $\mathrm{Na}$ construção do dispositivo de análise, os gestos de leitura do analista imbricam-se, por sua vez, na tensão entre descrição e interpretação (PÊCHEUX, 2006, p. 19). Pensar dessa forma é já se encontrar reterritorializando a noção de língua, ${ }^{2}$ produzindo um deslocamento que inclui o equívoco no espaço discursivo não logicamente estabilizado bem como uma outra concepção de falante, ou seja, não mais um suposto falante que saberia do que fala e cuja enunciação seria reflexo de "propriedades estruturais independentes de sua enunciação" (2006, p. 31). Os equívocos e as falhas não resultariam de um acaso que quebraria a lógica de uma língua estruturada e autônoma, de um pensamento estabilizado ou de uma rotina cotidiana organizada. $\mathrm{E}$, indo além, o autor mostra que, sendo qualquer enunciação exposta ao equívoco da língua (sua expressão), a deriva nos processos de produção de sentidos é sempre possível.

Vale destacar, ainda, que o real evocado por Pêcheux aponta para outro tipo de saber, não redutível ao que se espera do saber produzido, por exemplo, na universidade, ou das coisas a serem sabidas pelas ciências. Como afirma o autor,

[...] um real constitutivamente estranho à univocidade lógica, e um saber que não se transmite, não se aprende, não se ensina, e que, no entanto, existe produzindo efeitos (2006, p. 45).

De que saber fala Pêcheux aqui? Colocado dessa maneira, essa noção de saber encontra na psicanálise forte ressonância. Para a psicanálise, leia-se aqui tal como formulada por Lacan em sua releitura de Freud, certamente se trata de um saber singular, e justamente por ser singular não se se apre(e)nde, não se transmite em uma aula, nem é generalizável, mas permanece produzindo efeitos. É um saber que ultrapassa o sujeito, e, sendo irredutível e efêmero, só é apreensível por um analisante em processo de análise, processo esse que tem no psicanalista uma testemunha do que se produziu. Considerando que Pêcheux está colocando sob lentes bastante críticas tanto a 
evidência de necessidade de "um mundo semanticamente normal" (2006, p. 34) quanto discursos científicos que, excluindo o sujeito desejante, buscam a produção de um saber totalizante, unificante e sistematizador, ${ }^{3}$ a inclusão, justamente, do real como ponto de impossível bem como a inclusão de um saber que só se sustenta na singularidade do um-a-um, promove um deslocamento e propõe um caminho no discursivo que se abre para 'mostração' da presença-ausência do inconsciente. $\mathrm{O}$ inconsciente, ou seja, o que se impõe para todos, mas que não se mostra nunca de uma mesma ou única maneira.

Leite, por sua vez, discute a subjetividade na linguagem em alguns textos de Pêcheux, sobretudo no já mencionado Discurso: estrutura ou acontecimento, tendo em vista a hipótese do inconsciente e o fato da menção ao real como "lugar do acontecimento" (LEITE, 1994, p. 15), singular e contingente, na estrutura. A hipótese do inconsciente, ou melhor, o que usualmente nomeia-se como descoberta do inconsciente por Freud, aponta para uma ruptura com uma tradição filosófica e linguística sobre a centralidade do falante, daquele que enuncia o eu. Em tal tradição, a menção ao eu supõe e implica a consciência, ou seja, a certeza da consciência do sujeito que toma a palavra. Leite chama a atenção para a progressiva inclusão da categoria do Outro na obra de Pêcheux, e como essa categoria encontra-se articulada a alterações na conceituação de estrutura. De acordo com Leite, o avanço da proposta psicanalítica está na consideração de que a linguagem, ou o simbólico, ou o Outro barrado, conforme Lacan, é por si, e em si, furada, esburacada, ao mesmo tempo em que produz o furo real (LEITE, 1994, p. 19).

Leite retoma o título do já mencionado texto de Pêcheux e, considerando fortemente uma intervenção da psicanálise, reconhece que o autor inclui a psicanálise em seu projeto de teoria do discurso, mas propõe um deslocamento bem radical a esse respeito, ao afirmar a necessidade de referência ao real tendo em vista a singularidade do acontecimento na estrutura. Diz a autora: “[...] oferecemos a seguinte leitura: o Outro é esburacado, a estrutura comporta um furo, o lugar do acontecimento" (LEITE, 1994, p. 21). Tematizar a linguagem e o sujeito desse ponto de vista é, do lado da linguagem, salientar a necessidade de pensá-la de forma diferenciada, e, do lado do sujeito, enfatizar sua divisão, ou seja, demarcar que "há um saber que não se sabe", e que se trata de um saber sem mestre, conforme afirma Lacan (1985, p. 19) sobre o inconsciente.

\section{Testemunho: primeiras impressões}

É na ordem da dimensão de um indizível, de um furo presente na linguagem, que testemunho será pensado aqui. Logo, uma pergunta já se formula: como seria possível transmitir algo indizível?

Deve-se lembrar de que o testemunho é da ordem do memoriável, esse é um 
dos seus aspectos. Dar um testemunho aponta para um falar urgente, para $o$ não esquecer e para um não deixar os outros esquecerem. Pensemos aqui em Primo Levi, uma perfeita testemunha (AGAMBEN, 2008, p. 26), que logo nas palavras introdutórias do seu livro $E$ isto um homem? formula esse imperativo de relatar o que havia passado no campo de concentração em termos de perda da dignidade de si, em uma posição limite, nem vivo nem morto e, sobretudo, sem voz. Levi deseja contar aos outros o que aconteceu, e isso tomou "caráter de impulso imediato e violento" (LEVI, 2013, p. 8)

Também para Rigoberta Menchú, que relata os massacres sofridos por seu povo na Guatemala, dar um testemunho sobre o vivido é crucial. Nas palavras de Levi (2013), testemunhar sobre o vivido traumático é uma forma de liberação interior. Nos relatos de Primo Levi, de Rigoberta Menchú e, também, no âmbito do funcionamento das Comissões da Verdade, no conjunto de testemunhos que relatam processos de extrema violência contra a própria condição humana, situações em que se perde o direito ao uso da língua, em que a fala é totalmente impossibilitada e em que os referenciais de vida cotidiana, do ordinário de sentidos, em um mundo semanticamente estabilizado, são apagados, encontra-se o que estamos chamando de dessubjetivação. Não se trata, apenas, de uma ausência de significação para si ou sobre si mesmo, em função do desmantelamento de uma memória em que o sujeito se ancorava para suportar seus dias. Trata-se, também, da insistência em uma única significação (interpretação) mortífera que advém do Outro, que interpela o prisioneiro como um nada e $o$ joga nesse nada, em que nada do humano, mesmo ações rotineiras, como o barbear-se, faz algum sentido. Essa experiência, o real desse acontecimento, marca no relato de Primo Levi sua tentativa de inscrição no simbólico:

[...] nos damos conta de que a nossa língua não tem palavras para expressar esta ofensa, a aniquilação de um homem. [...] quem perde tudo, muitas vezes perde também a si mesmo; transformado em algo tão miserável [...] Infindáveis e insensatos são os rituais obrigatórios. [...] Quando a necessidade aperta, aprende-se em breve a apagar da nossa mente o passado e o futuro (LEVI, 2013, p. 24, 25, 32, 35).

No entanto, os inúmeros textos escritos, publicados, e as inúmeras entrevistas concedidas por Levi permitem que nos indaguemos sobre a tríade real, simbólico, imaginário. A captura imaginária que faz retorno e se entrelaça na incessante escritura poderia bordar de fato o real desse acontecimento? Cogitamos sobre a (im)possibilidade de inscrição no simbólico, tanto no que concerne à busca de paz na experiência única vivida por Levi, quanto a dar paz aos mortos.

Zizek (2006, p. 14) dirá que o impacto do Holocausto pode ser avaliado justamente pela impossibilidade de sua inscrição em alguma narrativa histórica já existente, anterior ao acontecimento em si. Esse espaço simbólico anterior, que assegurava às narrativas históricas sua historicização, não insere o Holocausto 
em nenhuma seriação. $\mathrm{O}$ acontecimento do Holocausto escapa à seriação histórica. Ele é puro corte. Puro acontecimento real, aqui compreendido como real da história, a posteriori bordejado por tentativas de simbolização, como faz Primo Levi em seu relato, mas que deixa um resíduo indizível e resistente à historicização. Nem tudo é possível contar.

Nesses casos, como nos de Primo Levi e Rigoberta Menchú, não valeria o que Yerushalmi afirma? Ou seja, em testemunhos dessa natureza, o "antônimo de esquecimento não seria memória, mas sim justiça" (YERUSHALMI, 1988, p. 10). Justiça a ser conferida aos que não conseguiram voltar e, também, justiça a ser conferida aos sobreviventes. Discutimos, até aqui, o Holocausto, mas também poderíamos estar falando das ditaduras e de seus mecanismos de tortura, repressão e atentados políticos além da imaginação.

\section{Memória e esquecimento}

Se testemunho é dar ordem a essa tentativa de inscrição na história, do memoriável, e se, de outro modo, estou pensando aqui que a linguagem, logo, o memoriável a partir da linguagem, é o não todo-dizível, proponho incluir uma reflexão sobre o esquecimento, pois o esquecer caminha lado a lado com o testemunho daqueles que querem registrar determinadas memórias. Falo do esquecimento pelo ângulo da impossibilidade de um tudo lembrar-se do que está no cerne da constituição do sujeito. O que seria o esquecimento? O que é, como funciona o esquecer? Por que esquecemos ou por que, ao contrário, insistimos em lembrar, supondo na memória a verdade?

No início de 2015, uma frase circulou pelo Facebook, frase que, de início, compartilhei sem pensar muito. A frase era: "Deixe para trás tudo o que não te leva pra frente". Frase construída com antônimos, frase de efeito, dessas que fazem estilo autoajuda, e que só retornou para mim como enigma quando percebi que vários amigos da rede social a haviam curtido e feito comentários entusiasmados. Apenas nesse só-depois da leitura dos outros, questionei-me: o que seria esse deixar para trás? Deixar pra trás tudo? Tudo?, ou seja, todo um saber memoriável?

Esse "deixar para trás" da frase não estaria remetendo à possibilidade de um esquecimento totalmente voluntário, como um gesto pessoal de colocar algo, alguém ou uma situação nessa zona do não querer lembrar mais de algo, de alguém ou de alguma situação? Tomado por esse ângulo, esse esquecer alguma coisa do enunciado remete a um esquecimento inscrito na ordem de um saber alguma coisa, ou, ainda, de um esquecimento inscrito na ordem do devia ter feito alguma coisa (MILNER, 1988).

É na materialidade do funcionamento da língua (portuguesa, nesse caso) que se constitui o efeito de evidência do indivíduo consciente; assim, é na e pela língua que se materializa a inscrição daquele que afirma "esqueci...". 
Questionando, justamente, os efeitos de evidência inscritos na materialidade da língua, Milner dirá:

Indivíduo, dever e consciência, aqui está então o que designam, sem o saber, aqueles que são indiferentes às palavras e acreditam no gênero comum de todos os esquecimentos (MILNER, 1988, p. 64, tradução nossa).

Há, por um lado, retomando o enunciado do Facebook, o efeito de evidente possibilidade inscrito na materialidade da formulação "deixar para trás", que coloca o sujeito em uma posição consciente, autônoma e totalmente voluntária, e, por outro, há um esquecer relacionado a um saber que não se sabe (que se sabe), como no episódio do esquecimento do nome próprio Signorelli, exaustivamente investigado por Freud, caso relatado em Psicopatologia do cotidiano sobre seu próprio esquecimento. ${ }^{4}$

Desconfiar dessa ilusão de certitude provocada por processos de produção de sentidos, tal como se inscrevem na base material da língua, esse é o ponto. Em outras palavras: a que efeitos de sentidos o verbo esquecer e o substantivo esquecimento estão submetidos e submetem quem os utiliza?

\section{Assim,}

Se há o esquecimento, nos diz Milner, então há outra coisa que o fantasma da memória: há um real, como acontecimento singular e contingente, o qual faz signo ao sujeito na forma do esquecimento (MILNER, 1988, p. 65, tradução nossa).

Signo, na acepção lacaniana, é o que representa algo para alguém. Nessa concepção encontra-se a via dos senti- dos, da captura imaginária em que o eu se encontra alienado. $\mathrm{O}$ significante em Lacan, repensado a partir dos apontamentos de Saussure, é o que não porta sentido algum, e que se impõe ao sujeito com sua lógica própria, que é a da relação S1... S2. Uma lógica que não porta conectivos e que, como nos sonhos, opera a partir de relações metaforonímicas, promovendo um jogo de remissões, condensações, deslizamentos e substituições que movimentam os significantes sem fechar sentidos.

Nesse jogo, ou rede de remissões, o simbólico é estruturado, portanto, como um encadeamento significante não fechado, e que, em seu modo de operação, deixa algo como resto irredutível ao significante. Um resto que se tenta abordar pela linguagem. ${ }^{5} \mathrm{O}$ sujeito, nos diz Lacan, é "determinado pela fala e pela linguagem [...] nasce no que, no campo do Outro, surge o significante. [...] antes não era nada senão sujeito por vir - se coagula em significante" (LACAN, 1985, p. 187, grifo nosso). O sujeito se engendra de um nada, de um por vir, e se "coagula em significante", ou melhor, dividido pela e na cadeia significante, sempre representado de um significante para outro. Dito de outra maneira, o sujeito encontra-se em movimento, em errância, sendo representado de um significante para outro; sujeito do inconsciente é efeito de se estar na linguagem.

A subjetividade, sob esse ponto de vista, não é compreendida no eu e nos seus signos com os quais se representa, ou seja, 
filhos, carros, documentos de identidade, cor de olhos, memórias, títulos, enfim, todo o conjunto de elementos predicativos ou sígnicos em que o eu se supõe representado e onde (se) supõe encontrar enquanto unidade autônoma e consciente. $\mathrm{O}$ eu é do registro do imaginário, ilusório, alienado, e está sempre se defrontando com o enigma advindo do sujeito do inconsciente que fratura as certezas [do eu]. Assim, quando se propõe de fato um trabalho com a perspectiva psicanalítica, compreende-se a subjetividade como o que escapa, o que não (se) fecha nas interpretações, o que é fugidio e não se reduz a alguma determinada representação. Lacan irá se valer do neologismo linguisteria para afirmar que o que propõe não é do campo da linguística, uma vez que a psicanálise introduz o sujeito do inconsciente, do desejo inconsciente, enquanto que a linguística, enquanto ciência, foraclui o sujeito. "A linguagem é condição do inconsciente", como afirmou Lacan inúmeras vezes, e "o inconsciente é a condição da linguística" (LACAN, 2003, passim).

Voltemos aos nossos pontos de discussão sobre: testemunho, memória e esquecimento. De um lado, o fantasma da memória, aquilo que, pela via do imaginário, insistimos em recordar de terminada maneira, muitas vezes em repetições infindáveis. De outro, o furo na memória, que insiste em ficar sem representação quando se dá o esquecimento. Real, em psicanálise, é o registro do impossível, o que escapa de inscrição no simbólico. Trata-se do saber que está no real, um res- to que a operação significante, de entrada no simbólico, não deu conta, estamos no plano dos objetos. Essa dimensão do real, do que foi perdido pelo infans (como vivo, orgânico) em função de sua entrada no simbólico, não cessará de tentar se escrever, ou como diz Lacan: "não cessa de não se escrever" (1990, p. 127).

Sabemos que o lembrar e o esquecer estão tensionados, operam nessa tensão e têm funções diferentes. Em termos da análise do discurso, Pêcheux já chamava a atenção para isso: a memória é lacunar, e na memória já se encontra a marca do esquecimento. E o que é bonito é justamente que o esquecimento, conforme Pêcheux, não está designando algo que em algum momento se soube, mas, sim, "o acobertamento da causa do sujeito no próprio interior de seu efeito" (PÊCHEUX, 1988, p. 183).

Mariani (2012), para falar do esquecimento, trouxe a metáfora lacaniana do "texto descompletado": nas tensões do lembrar-e-esquecer/esquecer-e-lembrar estão as tentativas do sujeito do inconsciente de falar pelas falhas, pelos buracos que vão se abrindo e esgarçando o dizer. $\mathrm{O}$ inconsciente é causa, e porta um saber sem sujeito. Dessa forma, o voluntarismo pretensamente consciente de um indivíduo naquele 'querer esquecer' (deixar pra trás), encontra-se no registro do eu, absorvido pelo imaginário. Porém, algo sempre incomoda e faz retorno, ou seja, busca brechas para se fazer ouvir. E retorna justamente porque o esquecimento nos constitui, está na gênese da 
divisão subjetiva. Falar das lembranças, do memoriável, é deparar-se também com o esquecimento, logo, com o real que sinaliza no campo da fala e da linguagem, a impotência das palavras e um indizível na/da apreensão dos objetos.

\section{Testemunho e transmissão}

De início, deixo de lado o sentido jurídico de testemunho, que é o de alguém que, uma vez chamado para depor em um processo, afirma ou nega o que lhe é perguntado; e deixo de lado também o sentido dicionarizado, o testemunho como "o que indica a existência de algo, uma demonstração cabal, plena, uma afirmação fundamentada" (HOUAISS, 2001, p. 1962).

Quanto à etimologia da palavra testemunho, Agamben nos diz que em latim há dois termos: "1. Testis (o que se põe como terceiro) em um processo entre dois contendores; 2. Supertes, aquele que viveu algo, atravessou até o final um evento e pode dar testemunho disso" (2008, p. 35). Ainda conforme Agamben:

Em grego, testemunho é Martirs. Na história do catolicismo, Martirium é a palavra que indica aqueles (cristãos) que tinham sido perseguidos e mortos. Assim, em Martir/Martirium há um testemunho de fé, no qual o recordar é crucial (2008, p. 36).

Para o que está se discutindo aqui, testemunho supõe uma implicação subjetiva no que se está narrando. Nesse sentido, é um termo vinculado a alguém que passou por alguma experiência de vida (um even- to, nas palavras de Agamben) traumática e que, com o relato disso que vivenciou, pode dar um testemunho, ou seja, transmitir aos outros o que foi ter passado por essa experiência. Dar testemunho é transmitir, por via oral ou escrita, essa experiência. Há, portanto, sujeito inscrito no testemunho, há enunciação, nos termos da psicanálise, naquilo que se narra.

Contudo, o título deste trabalho aponta, justamente, para um fracasso da linguagem em falar de um "todo vivido", uma vez que a linguagem é insuficiente e apenas faz borda na tentativa de dar conta do real da experiência, ou evento, ou acontecimento que mergulha com violência o sujeito.

Primo Levi suicidou-se em 1987. Como apresentado no início deste texto, reiteradas vezes, ao longo da vida, em entrevistas ou em outros livros escritos, ele marcou fortemente sua insistência em testemunhar, em narrar sua experiência para "os que sabiam", para "os que não queriam saber", para "os indiferentes". Assim, na posição de superstes, o escrever em Levi traz a marca dessa insistência do testemunho, condição daquele que quer contar para os que não sabem, o que ele sabe sobre o aniquilamento da vida em Auschwitz.

Agamben (2008), que encontrou Levi diversas vezes, registra a divisão de Levi entre um sentimento de culpa por ter sobrevivido e a sensação de "paz" consigo próprio em função do testemunho insistentemente transmitido. $\mathrm{O}$ relato inúmeras vezes realizado por Levi leva-o a nomear uma "zona cinzenta", quase como um 
novo elemento ético, "situado aquém do bem e do mal", e que diz respeito ao "sub-homem”, conforme Agamben (2008, p. 30).

A zona cinzenta demarca um lugar muito específico de sobrevivência do sub-homem. Levi destaca que alguns prisioneiros eram designados para tarefas abjetas, como aqueles que eram responsáveis pela administração das câmaras de gás. Levi traz vários testemunhos desses sobreviventes, sinalizando tanto o horror quanto o absurdo dos relatos, tanto a silenciosa angústia quanto o sentimento de vergonha que a todos marcava. Agamben (2008) questiona-se então: E nós, diante da angústia e da vergonha da experiência desse outro, diante desse testemunho, desse real, dessa história que não se inscreve em nenhuma série memoriável ou possível, em pleno século XXI, podemos nos dizer afetados pelo testemunho que Levi insiste em transmitir?

Genéviève Morel (2001, p. 217), que tem um extenso e belíssimo texto sobre Primo Levi, menciona uma entrevista concedida por ele em 1983, quando se diz desencorajado por ver que a geração seguinte à sua, mesmo seus filhos, não o querem escutar. É como se "falasse uma língua diferente", afirma Levi, como se o Outro, o destinatário, não conseguisse ouvir o que há para ser dito.

Essa insistência no testemunho também é sublinhada em Rigoberta Menchú (2013), mas de outra forma, em entrevista recentemente concedida: "Eu jurei não me calar frente à tortura, à barbárie. Então, estive por trás de denúncias pú- blicas, de falar publicamente, de dizer a minha verdade".

Diferentemente de Primo Levi, ao ser perguntada sobre "O que resta para você fazer?", Rigoberta responde enfáticamente:

Escrever a verdade. Não apenas a memória de Rigoberta Menchú como uma memória coletiva, mas o que tanto temos feito... Então, eu gostaria de escrever quatro ou cinco livros de diferentes facetas, desde menina, na juventude, na militância - porque sou uma militante - , meus professores, os desafios que a vida nos trouxe, um deles é a violência e há outros medos que tivemos e é preciso escrever isto (MENCHÚ, 2013, não paginado, grifo nosso).

Tanto em Primo Levi quanto em Rigoberta Menchú tem-se o testemunho da posição de exclusão social daqueles que sobrevivem a um sofrimento muito grande, muitas vezes de ultrapassamento de uma experiência de quase morte. Situações de dessubjetivação e de privação extrema, situações em que impera uma total falta de ética, que retira do sujeito qualquer vestígio de dignidade para transformá-lo em dejeto. Pela crítica literária, a escrita testemunhal é trabalhada com:

[...] uma concepção de linguagem ligada ao trauma. [...] Assim, a base do testemunho consiste em uma ambiguidade: por um lado, a necessidade de narrar o que foi vivido e, por outro, a percepção de que a linguagem é insuficiente para dar conta do que ocorreu (GINZBURG, 2008, não paginado).

Em Levi, e em tantos outros prisioneiros, o testemunho marca também a angústia e a culpa por ter sobrevivido.

O que interessa para a psicanálise não se vincula à discussão entre ficção e realidade, pois isso seria dar suporte 
imaginário à inteireza do Outro. A questão está em outro lugar: Freud e Lacan nos ensinam que a verdade é da ordem do inconsciente, é da ordem de um saber e só pode ser semidita. Tudo não se diz. $\mathrm{E}$ algo se transmite, se alguém ouvir.

Morel (2001), em sua análise do testemunho de Primo Levi, sobretudo no momento em que se refere ao sonho por ele narrado, demarca o ponto de angústia extrema de quem fala de sua experiência traumática e não é escutado, recebendo apenas a indiferença dos outros. Um sonho que passa um sentimento de solidão, de desamparo, de retorno ao que é mais constitutivo, mais originário:

Surgem a minha irmã, alguns amigos meus não identificados e muito mais gente. Todos estão a ouvir-me, enquanto conto precisamente isto: o silvo em três notas, a cama dura, o meu vizinho que queria afastar mas que tenho medo de acordar porque é mais forte do que eu. Falo pormenorizadamente também da nossa fome, do controlo dos piolhos e do Kapo que me bateu no narize a seguir ordenou que fosse lavar-me porque sangrava. é um prazer imenso, físico, inefável estar na minha casa, entre pessoas amigas, e ter tantas coisas para contar; mas não posso deixar de me aperceber de que os meus ouvintes não prestam atenção. Pelo contrário, são totalmente indiferentes: falam confusamente de outras coisas entre si, como se eu não estivesse lá. A minha irmã olha para mim, levanta-se e vai-se embora sem dizer nada (LEVI, 2013, p. 61).

Um sonho que testemunha a "dor em estado puro, real sem mediação nenhuma”, nos diz Morel (2001, p. 221). E, a partir de Agamben, afirma: "O testemunho aparece somente onde aparece uma impossibilidade de dizer algo" (MOREL,
2001, p. 221). Apesar de sua insistência em dizer, e apesar do fato de que realmente dava seu testemunho, a dor de Primo Levi, supõe Morel, era de outra ordem, o que o teria levado ao suicídio.

$\mathrm{O}$ que realço aqui como traço que circunscreve um testemunho são os pontos de real em que se tropeça, e seus efeitos na direção da cura, ou melhor, seus efeitos no momento de concluir uma análise. Lacan destacava a relevância, na formação de um analista, do testemunho de análise, um testemunho da experiência com o inconsciente e os efeitos dessa experiência da vida de cada um. Só o sujeito pode dar um testemunho sobre o real do inconsciente, um testemunho para alguns outros dispostos a ouvir. Difícil momento esse de um final de análise, terreno de linguagem arenoso e árido: como transmitir uma experiência totalmente surpresiva, pontual e evanescente sobre a qual um dizer de anos se esgarça e se interrompe, mas que, ao fim e ao cabo, não para?

Testemunho de análise, para mim, tem a ver com isso: testemunhar sobre um dizer que diz de um dizer esgarçado e já acontecido, é dizer do encontro com a falta de garantias, de insígnias, de sentidos. Um dizer que segue adiante, que passa por seus furos e entre as diferenças significantes, movendo-se discursivamente, com um incansável trabalho com a língua, sobre a língua e em lalíngua. Morel fala do testemunho de percurso de análise em que: "[...] alguns sujeitos conseguem, através de um esforço rigo- 
roso e um árduo trabalho sobre a língua, extrair o que foi para eles esse algo impossível de ser suportado. Dão forma de um discurso para poder transmiti-lo a outros" (MOREL, 2001, p. 234).

Voltando ao testemunho, como destaca Leite, "[...] o que denominamos de testemunho o é sempre por já delegação, substituto da testemunha, e sobre ele pesa o encargo de testemunhar, tendo sobrevivido" (LEITE, 2009, p. 178). Pensemos, então, no sonho do Primo Levi. Um sonho é algo que não se espera, não se imagina que vá acontecer do modo que acontece. Não há como ser antecipado: um sonho simplesmente é. Nem simbólico nem imaginário dão conta do sonho, porque ao contarmos o sonho, ele já se torna outra coisa. No sonho, o sujeito é autor e testemunha simultaneamente. Só o sujeito sonhador, em sua singularidade, pode dar o testemunho de seu próprio sonho. Com o relato do sonho, tem-se no só-depois o testemunho do sonhador, o testemunho de uma singular experiência com o real.

\section{Só mais um pouco}

Tendo em vista essas reflexões, cito o documentário A morte inventada (2009), filme que retrata o que é juridicamente chamado de alienação parental, com roteiro e direção de Alan Minas. O que pretendo discutir é a questão do testemunho tomando como base o que haveria de real nos testemunhos que pais e filhos dão ao longo do documentário sobre a separação que viveram e que deixou marcas em suas vidas.

Dois apontamentos se fazem necessários antes de prosseguir discutindo e comentando o documentário: quero entremear, neste texto, a ideia de testemunho enquanto transmissão do real que, como já mencionado, está em jogo em uma experiência analítica, e testemunho enquanto relato de experiências (traumáticas) vividas.

Indaga-se, muitas vezes, sobre o caráter testemunhal de relatos e depoimentos de experiências. $\mathrm{O}$ que faria de um relato um testemunho? Qualquer relato seria um testemunho? Não se trata de atribuir valor testemunhal a quem tem muita experiência ou vivência em determinada situação, por mais traumática que seja; não se trata, portanto, de uma memória para ser propagada. Qualquer um pode se valer de um tempo decorrido em que se adquiriu experiência em uma vivência traumática para daí extrair elementos a serem ensinados. Porém, nem tudo o que é vivido é da ordem da experiência de um acontecimento, experiência em termos analíticos, como sendo "aquilo que não se imagina” (LACAN, 1982 apud LEITE, 2009, p. 78). Assim, cabe a pergunta: haveria em qualquer depoimento, em qualquer narrativa, um testemunho a ser transmitido no sentido analítico? O que implicaria efeitos de transmissão?

Passo, agora, ao documentário, cujo título - A morte inventada - remete a enunciados efetivamente ditos durante as filmagens, como "morte do pai vivo", 
"matar o pai em vida". Inventada, aqui, remete ao que seria "coisa inventada de modo astucioso", conforme Houaiss (2001, p. 1641).

O documentário é o registro de um vasto conjunto de depoimentos dados por pais e filhos sobre o afastamento provocado pelas mães após o divórcio. Crianças que, impedidas do convívio com o pai, ficaram reféns de um gozo sem limites da mãe. São relatos que narram uma grande dor, um vazio e um conflito subjetivo tanto de parte dos filhos quanto dos pais. "Minha mãe era maravilhosa, sempre presente, carinhosa... E eu lembro que a mãe maravilhosa falava muito mal do meu pai" (A MORTE..., 2009). Em outro momento, entremeando com lágrimas e silêncios, diz uma das jovens:

Não precisava ter agora esse buraco que eu tenho... eu sinto muita falta, sabe? (silêncio) E com a terapia eu vi que para poder caminhar, sabe? Eu precisava cortar...e cortar minha mãe da minha vida foi muito complicado (AMORTE..., 2009).

São lembranças de infância e de adolescência que registram situações de perda da referência paterna, engendrando uma filiação que só se deixa consistir imaginariamente para o sujeito a partir do discurso materno: "Fiquei 11 anos sem vê-lo. [...] Só fui rever meu pai aos 19 anos, quando saí de casa". Na tentativa de escrever essa lacuna imposta pelas contingências da vida, muitos vão atrás de pedaços da própria história no relato dos outros:
Em alguns casos, para chegar à cura, basta arregaçar a camisa e mostrar onde dói, em outros, é preciso arregaçar a pele e mostrar aonde dói. Aqui não cabem as palavras... (A MORTE..., 2009).

Esse acontecimento ininteligível para a criança retorna em sua fala adulta, marcada por silêncios, pausas, lágrimas, ou, ainda, o que resta da criança, que tenta construir sua história a despeito de ter sido objeto de gozo da mãe. As omissões, as falhas persistem, por mais que as palavras e as metáforas usadas tentem dar conta do vivido durante o testemunho:

Aí a minha mãe... não lembro... a gente voltou para o Rio... a gente ficou do lado da minha mãe... a gente tomou as dores... eu não sei qual era a verdade... estar com meu pai curtindo, era como estar traindo a minha mãe... (A MORTE..., 2009).

A questão não é a ausência do pai, mas o ter ficado aprisionado ao pai destituído pelo discurso materno. Entre enunciados e enunciação vacilante, 0 sujeito tenta cernir o vazio, tenta habitar um tempo passado que não há mais, sem saber exatamente o que virá a ser.

Só agora, a essa altura da vida, fui conhecer o mais amargo dos sentimentos. A injustiça é uma onda de 10 metros que te arranca de dentro de si e faz tudo te apagar. Falta chão, falta ar, falta voz. Você perde o rumo, vc perde o prumo. Não sabe mais aonde fica o céu. Por eternos 3 segundos você prova o gosto da água do mar, o gosto do sal, da areia, da morte. A razão e os sentimentos submergem e afloram os seus mais profundos instintos. É você no avesso, primitivo, em carne viva. Esse sentimento veio morar comigo (AMORTE..., 2009). 
Esse sentimento de carne viva passa a morar com o sujeito, presença real do indizível da experiência da separação. Entendo esses depoimentos como testemunhos da passagem por uma experiência que, no só-depois, permite que algo gire e venha a inscrever a possibilidade de outra coisa na vida subjetiva. Porém, algo passa nesses testemunhos? Algo se transmite?

Ainda há um ponto para pensar em relação ao documentário. Refiro-me ao tempo tal como foi descrito em um dos testemunhos: "O tempo não seguiu as regras do jogo. Eu fiquei ali congelado. Todo mundo perdeu" (AMORTE..., 2009).

Em O tempo lógico, Lacan (1998) explica a lógica da modulação do tempo no movimento do sujeito, localizando três instâncias: o instante de olhar, o tempo para compreender e o momento de concluir. Não se trata, segundo Lacan, de uma temporalidade cronológica como a dos ponteiros do relógio apontando para o passar dos minutos. Nem tão pouco um tempo formal, em uma inscrição social, isso seria reduzir a temporalidade própria do sujeito a uma organização temporal que obedece a outras leis. O sujeito, ressalto, move-se em uma temporalidade própria à Outra Cena.

A temporalidade em que o sujeito se move se articula diferentemente, em "uma descontinuidade tonal", como diz Lacan, em cada uma dessas modulações próprias ao instante de ver, ao tempo para compreender e ao momento de concluir, o que marca o valor e a função diferenciada de cada modulação.
Há que se passar por esses momentos em sua lógica própria e ao mesmo tempo singular de cada um. O instante do olhar e "seu tempo de fulguração" tem em seu movimento a modulação de "uma matriz ainda indeterminada", uma temporalidade de indeterminação do sujeito que pode, conforme Lacan, "incluir todo o tempo necessário para compreender" (1998, p. 205). Os limites entre o instante do olhar e o tempo para compreender são imprecisos e reabsorvem-se ao longo da construção, em análise, da encenação imaginária em que o sujeito se encontra aprisionado e indeterminado.

Se é na absoluta ignorância da repetição que o sujeito se mostra, é no falar em análise que se estende pelo tempo de compreender, que se opera o mal entendido (da ordem da presentificação das diferenças significantes) na descontinuidade do retorno do não simbolicamente representável. O real, sabemos em nossa experiência de análise, não o buscamos, apenas tropeçamos nele, o que impõe questionamentos; e o sujeito, em sua busca de sentidos, de um pouco de certeza, está sempre se deslocando, sempre tentando se engatar entre um significante e outro, o que só faz marcar mais e mais sua falta de lugar na cadeia significante. Não está lá onde se busca: as palavras não encontram.

O tempo subjetivo do momento de concluir é para concluir que o tempo para compreender se encerra: uma conclusão a que somente o sujeito pode chegar, "passado o tempo para compreender 
o momento de concluir", como afirma Lacan (1998, p. 206). O tempo para compreender encerra-se no momento em que o sujeito chega a uma posição desejante, sua posição de verdade como desejante.

Mas seria assim tão transparente? $\mathrm{Na}$ tensão das tonalidades e descontinuidades da modulação temporal subjetiva, o sujeito duvida dessa verdade a que chegou, duvida, portanto, do momento de concluir, como nos diz Lacan. Ao mesmo tempo, dá-se conta de que só pode duvidar se atingiu, ainda que de modo fugaz, a verdade do momento de concluir: é porque algo dessa instância, o momento de concluir marcou-se em termos de uma experiência subjetiva. E o momento de concluir abre-se para um novo instante de ver em seus limites imprecisos com o tempo de compreender em um desenrolar da temporalidade que se escande e se esconde em seu próprio percurso.

Essa é a lógica da modulação temporal de um percurso de análise, ou de uma sessão de análise, ou do que se passa após uma sessão de análise. $\mathrm{O}$ inconsciente não tem hora marcada. Um percurso cujo final temporaliza-se subjetivamente, e que o sujeito só pode percorrê-lo sozinho, quando "o tempo subjetivo do momento de concluir objetiva-se enfim" (LACAN, 1998, p. 210). Um acontecimento que implica um longo trabalho de luto, ou melhor, de lutos, e do sujeito diante do real.

No documentário, jovens e pais testemunham o espanto e, em muitos casos, o horror diante do discurso materno. Esse instante de olhar entrelaçado ao tempo para tentar compreender as tentativas de reencontrar um pai. Qual pai? No tempo para compreender, a necessidade de simbolizar o pai e de esgarçar a pregnância do imaginário. Seria possível falar em um momento de concluir? Se alguns sofrem e se queixam do discurso materno, ainda reféns desse gozo da mãe, outros recriminam o pai, que deveria ter se esforçado mais para barrar aquela mãe. Poucos se valem da lacuna vivida para fazer dela outra coisa. $\mathrm{E}$ nesse ponto, podemos perguntar pelos tantos jovens que o documentário não traz, aqueles que teriam feito da aridez do vivido uma invenção, ou melhor, uma reinvenção possível dentro do impossível de ser dito.

Diante do real da morte, só nos resta inventar.

\section{Témoignage: un événement dans la structure}

\section{Résumé}

Cet article thématise la question du témoignage soit du point de vue de l'analyse du discours, soit du point de vue de la psychanalyse. La notion de réel est mobilisée, et circonscrit un impossible d'être simbolisé. On fait la discussión du livre Se isto é um homem, écrit par P. Levi, et du docummentaire $A$ morte inventada, dirigée par Alan Minas.

Mots-clé: Témoignage. réel. Analyse $\mathrm{du}$ discours. Psychanalyse. 


\section{Notas}

1 Meu agradecimento a Mirta Fernandes, Ana Carnevale, Lucilia Romão e Lauro Baldini pelas leituras e sugestões feitas para a primeira versão deste artigo. Este texto foi apresentado, inicialmente, na X Ciranda de Psicanálise e Arte, realizada no Museu de Arte do Rio, e dois meses depois no IV Encontro do GTDIS, na Universidade Federal Fluminense, ambas as apresentações ocorreram em 2014. Uma segunda versão, ampliada, foi apresentada na Universidade Federal Fronteira Sul, como parte de uma mesa-redonda do Celsul, em 2015. A versão escrita e final aqui apresentada passou por releituras, reescrituras e avanços.

2 Como o autor chama a atenção, na terceira parte do texto, quando, citando Milner (1987), menciona a relevância do real da língua e afirma que "nada da poesia é estranho à língua" (PÊCHEUX, 1990, p. 50-51), ou seja, a compreensão do funcionamento das línguas passa necessariamente pela inclusão dos deslizamentos incessantes da materialidade linguageira.

3 A esse respeito, Soler afirma que "aucune épistémologie empiriste ne vaut ici, et, en effet, on ne peut espérer que l'inconscient délivre la théorie qui rende compte de l'inconscient. Ce savoir-là, il se construit et se diffuse à partir de l'étude des textes où il est déposé et que tous considèrent comme nécessaires à la formation" (SOLER, 2009, p. 83).

4 Sobre esse episódio do esquecimento de Freud, cf. Mariani (2012).

5 Leite, discutindo a maneira como Lacan relê Saussure, afirma: "ao introduzir no domínio da causa real do inconsciente a lei do significante, Lacan lê na Linguística saussureana e em Jakobson a descrição do funcionamento de uma estrutura que condiciona o fato de haver, como efeito, inconsciente. [...] é a própria inteligência do discurso inconsciente que impõe deslocamentos, sendo esta a razão pela qual Lacan objeta ao fato de que tudo que seja da linguagem dependa da Linguística" (1994, p. 36).

\section{Referências}

AGAMBEN, G. O que resta de Auschwitz. São Paulo: Boitempo, 2008.

A MORTE inventada. Sobre a alienação parental. Direção e roteiro: A. Minas. Rio de Janeiro: Caraminhola Filmes, 2009. (Documentário).

BLEGER, D. Trauma, historia y subjetividad. Virtualia, Revista digital de la Escuela de la Orientación Lacaniana, Buenos Aires, a. IX, sept. 2010, p. 34-38. Disponível em: <http://virtualia.eol.org.ar/021/template. asp?Actualidad-del-lazo/Trauma-historia-y-subjetividad.html>. Acesso em: 1 mar. 2016.

GINZBURG, J. Linguagem e trauma na escrita do testemunho. Revista Conexão Letras, Porto Alegre, v. 3, n. 3, 2008. Disponível em: $<$ http://seer.ufrgs.br/index.php/conexaoletras/issue/view/2581/showToc $>$. Acesso em: 1 mar. 2016.

HOUAISS, A. Dicionário Houaiss da Língua Portuguesa. São Paulo: Objetiva, 2001.

LACAN, J. O Seminário - livro 20. Rio de Janeiro: Zahar, 1985.

. O tempo lógico a a certeza antecipada. In: . Escritos. Rio de Janeiro: Jorge Zahar, 1998. p. 203-211. . (1970). Radiofonia. In:

Outros escritos. Rio de Janeiro: Jorge Zahar, 2003. p. 445-449.

LEITE, N. Psicanálise e análise do discurso: o acontecimento na estrutura. Rio de Janeiro: Campo Matêmico, 1994.

LEITE, Nina Virginia de Araujo. Transmissão da experiência: o estranho na narrativa. Trivium, Rio de Janeiro, a. I, ed. I, p. 75-83, $2^{\circ}$ sem. 2009. Disponível em: <http://www. uva.br/trivium/edicao1/artigos-tematicos/7-transmissao-da-experiencia-o-estranho-na-narrativa.pdf>. Acesso em: 28 fev. 2014.

LEVI, P. Se isto é um homem. Alfragide: Publicações D. Quixote, 2013. 
MARIANI, B. O esquecimento na memória. In: ROMÃO, L. M. de S.; CORREA, F. S. (Org.). Conceitos discursivos em rede. São Carlos: Pedro \& João, 2012. p. 153-174.

MENCHÚ, Rigoberta. Rigoberta Menchú: Jurei não me calar ante a tortura e a barbárie. Entrevista concedida a Sonia Santoro. Portal Vermelho, 17 de setembro de 2013. Disponível em: <http://www.vermelho.org. br/ap/noticia.php?id_noticia=224314\&id_secao $=8>$. Acesso em: 28 fev. 2014 .

MILNER, J.-C. Le matériel de l'oubli. In: YERUSHALMI, Y. H. et al. L'usages de l'oubli. Paris: Éditions du Seuil, 1988. p. 7-21.

. O amor da língua. Porto Alegre: Artes Médicas, 1987.

MOREL, G. Testimonio y real. In: Acheronta Psychoanalysis y cultura, Buenos Aires, n. 13, p. 217-264, jul. 2001.

ORLANDI, E. Introdução. In: PÊCHEUX, M. $O$ discurso: estrutura ou acontecimento. Campinas: Pontes, 2006. p. 5-9.

PÊCHEUX, M. (1988). O discurso: estrutura ou acontecimento. Campinas: Pontes, 1990.

O discurso: estrutura ou acontecimento. Campinas: Pontes, 2006.

SOLER, Colette. Ce que la psychanalyse enseigne. Contribution aux journées d'Espace Analytique, 14-15 mars 2009. p. 83-89. Disponível em: <http://www.champlacanienfrance. net/IMG/pdf/soler_M44.pdf>. Acesso em: 25 fev. 2016.

THÉRON, F. Avant-propos du traducteur. In: ZIZEK, S. La subjectivité à venir: essais critiques. Édition établie par F. Joly et F. Théron. Paris: Flammarion, 2004. p. 7-12.

YERUSHALMI, Y. H. Réflexion sur l'oubli. In: YERUSHALMI, Y. H. et al. L'usages de l'oubli. Paris: Éditions du Seuil, 1988. p. 7-21.

ZIZEK, S. La subjectivité à venir: essais critiques. Édition établie par F. Joly et F. Théron. Paris; Flammarion, 2006. 